\title{
Opportunities and challenges faced by private enterprises under the low-carbon economy and countermeasures
}

\author{
Lixing Zhou, ${ }^{1 *}$ \\ ${ }^{1}$ Guangdong Vocational Institute of Public Administration, Guangzhou 510800, China
}

\begin{abstract}
In the background of the rapid development of market economy, a large number of carbon dioxide emissions, leads to the obvious imbalance of carbon in nature. In recent years, the global temperature is getting warmer, the sea level is rising year by year, and the grain production is also significantly reduced, which will bring a great threat to the normal survival and development of human beings. In order to protect the environment on which human beings live, low carbon economy is put forward. Under the environment of low carbon economy, private enterprises are not only facing new development opportunities. At the same time, private enterprises are also facing new development challenges. If they want to develop further, they must actively deal with them. The author analyzes the opportunities and challenges faced by private enterprises under the environment of low carbon economy, and puts forward specific countermeasures, hoping to be helpful to the long-term development of private enterprises.
\end{abstract}

\section{Introduction}

Private enterprises occupy a very important position in the economic development of our country. With the continuous development of China's economy, the importance of private enterprises is becoming more and more prominent, private enterprises are not only facing new development opportunities. It also faces new challenges for further development. In the complex and changeable market environment with fierce competition, enterprises need to adopt effective strategies in the low carbon economy environment if they want to develop better. It needs to accurately grasp the development opportunities and effectively respond to the development challenges.

\section{2 the development opportunities faced by private enterprises in a low-carbon economy environment}

General Secretary Xi Jinping stressed at the Carbon Summit and Carbon Neutral Conference that achieving carbon summit and carbon neutrality is a systematic economic and social reform. Carbon peak and carbon neutrality should be included in ecological progress. We will work hard to reach a carbon peak by 2030 as scheduled, and achieve carbon neutrality by 2060 as scheduled. Under the environment of low-carbon economy, private enterprises should carry out low-carbon strategic transformation according to their own characteristics and actual situation in the process of development. To avoid falling into the misunderstanding of low-carbon economy and to avoid the waste of resources, the development opportunities faced by private enterprises under the environment of low-carbon economy are shown in Table 1.

Table 1 the development opportunities faced by private enterprises in a low-carbon economy environment

\begin{tabular}{|c|l|}
\hline $\begin{array}{c}\text { The development } \\
\text { opportunity of private } \\
\text { enterprise }\end{array}$ & \multicolumn{1}{c|}{ The specific performances } \\
\hline Low carbon food & $\begin{array}{l}\text { 1、 More and more people are suffering from obesity, and people are becoming } \\
\text { increasingly health-conscious. Low-carbon food will become a hot seller in the } \\
\text { food industry. } \\
\text { 2、In order to achieve the effect of weight control and blood sugar control, } \\
\text { people often eat some low-carbon food to reduce the intake of carbohydrates. }\end{array}$ \\
\hline Low carbon home & $\begin{array}{l}\text { 1、In the field of home decoration in China, green home furnishing and } \\
\text { environmentally friendly home products are popular, and low carbon life is }\end{array}$ \\
\hline
\end{tabular}




\begin{tabular}{|c|c|}
\hline & $\begin{array}{l}\text { being continuously promoted. } \\
\text { 2、 the introduction of low carbon technology, low carbon range hood, low } \\
\text { carbon disinfection cabinet and other low carbon products are bound to occupy } \\
\text { a larger share of the future market. }\end{array}$ \\
\hline Energy-efficient buildings & $\begin{array}{l}\text { 1、 Energy-saving buildings mainly include buildings that meet the national } \\
\text { technical standards for energy saving, such as walls, floors, shading facilities, } \\
\text { lighting equipment, air conditioning systems, etc. } \\
\text { 2、China always advocates sustainable development, and it is necessary to } \\
\text { dispose construction waste reasonably in accordance with China's relevant } \\
\text { policies on construction waste recycling and utilization. } \\
\text { 3、 Energy-saving buildings have brought new development opportunities for the } \\
\text { development of various energy-saving equipment. At the present stage, China's } \\
\text { government departments have introduced relevant policies, and formulated } \\
\text { corresponding subsidy policies for the use of energy-saving lamps. It is clear } \\
\text { that there is a lot of room for development in the energy-saving lamp industry. }\end{array}$ \\
\hline Low carbon agriculture & $\begin{array}{l}\text { 1. Climate change has brought great challenges to the development of } \\
\text { agriculture in China. The development of agriculture is not only faced with the } \\
\text { problem of water shortage, but also faced with the problem of fuel price } \\
\text { fluctuation. } \\
\text { 2. The greenhouse gas released by agricultural land is huge, so there is huge } \\
\text { space for the development of low-carbon agriculture }\end{array}$ \\
\hline Low carbon industry & $\begin{array}{l}\text { 1、 Low-carbon industry not only has low energy consumption, but also } \\
\text { relatively small pollution and relatively small emissions. } \\
\text { 2. Low carbon industry is the efficient use of energy, vigorously develop clean } \\
\text { energy, the emergence of low carbon industry reflects the change of the concept } \\
\text { of human survival. }\end{array}$ \\
\hline
\end{tabular}

\section{3 the development challenges faced by private enterprises in a low-carbon economy environment}

Under the environment of low carbon economy, the development of private enterprises is not only faced with new opportunities, but also with new challenges. The specific contents are shown in Table 2.

Table 2 Development challenges faced by private enterprises in a low-carbon economic environment

\begin{tabular}{|c|c|}
\hline Challenges faced by private enterprises & The specific performances \\
\hline $\begin{array}{c}\text { Excessive pressure on energy conservation } \\
\text { and emission reduction }\end{array}$ & $\begin{array}{l}\text { 1.In order to vigorously implement the energy conservation and } \\
\text { emission reduction advocated by the state, various provinces and cities } \\
\text { have formulated corresponding energy conservation and emission } \\
\text { reduction tasks and targets. } \\
\text { 2.some provinces and regions in the implementation of energy } \\
\text { conservation and emission reduction tasks, lack of adequate preparation. } \\
\text { The adoption of a one-size-fits-all approach to emergency } \\
\text { implementation has led to greater pressure on private enterprises to } \\
\text { conserve energy and reduce emissions. }\end{array}$ \\
\hline $\begin{array}{l}\text { It is difficult to meet the needs of industrial } \\
\text { development }\end{array}$ & $\begin{array}{l}\text { 1. In order to implement the task of energy conservation and emission } \\
\text { reduction, most provinces and cities arrange polluting industrial } \\
\text { enterprises in industrial parks. By the professional pollution treatment } \\
\text { company unified, centralized pollution control. Industrial enterprises } \\
\text { only need to pay the corresponding fees. } \\
\text { 2. With the continuous development of industrial enterprises, the scale of } \\
\text { production is expanding. The pollution produced is more and more } \\
\text { serious, and the pollutants produced are more and more complex. It is } \\
\text { difficult to ensure that the pollutants produced by enterprises can be } \\
\text { treated in a timely and efficient way only through the end treatment of } \\
\text { pollution, and it is difficult to meet the needs of current industrial } \\
\text { development. }\end{array}$ \\
\hline
\end{tabular}




\begin{tabular}{|l|l|}
\hline $\begin{array}{l}\text { The enterprise energy conservation } \\
\text { consciousness is weak }\end{array}$ & $\begin{array}{l}\text { 1.Some private enterprises are very weak in environmental protection } \\
\text { awareness, which leads to the development of low-carbon economy in } \\
\text { trouble. In particular, some small-scale enterprises attach too much } \\
\text { importance to their own economic benefits in the process of } \\
\text { development. The sense of responsibility for energy conservation and } \\
\text { environmental protection is poor, which will inevitably affect the further } \\
\text { development of private enterprises in the low carbon economic } \\
\text { environment. } \\
\text { 2. The comprehensive quality of internal staff in private enterprises } \\
\text { needs to be further improved, and they don't have realized the } \\
\text { importance of energy conservation and environmental protection. They } \\
\text { believe that the implementation of energy conservation and emission } \\
\text { reduction will inevitably increase their workload, so they tend to reject } \\
\text { energy conservation and emission reduction. In the low carbon economy } \\
\text { environment, if private enterprises want to further develop, energy } \\
\text { conservation and emission reduction is the only way for their } \\
\text { development. }\end{array}$ \\
\hline
\end{tabular}

\section{Coping strategies for further development of private enterprises in low-carbon economy}

\subsection{Take low carbon as the core of the enterprise's strategic concept}

In the low carbon economic environment, the nature of the environment itself has a more profound impact on the strategic development of enterprises than any other stage in the past. Therefore, in the process of operation and development, private enterprises must re-examine the nature of low carbon economic environment and the characteristics of the current era. In low carbon economic environment, the interaction between enterprises and the environment will gradually replace the active influence of enterprises on the environment. Private enterprises need to realize that the development of low-carbon economy is likely to lead to a huge change in the pattern of global economic development, thus triggering the industrial revolution. If private enterprises want to win a certain development advantage and gain greater competitiveness in the competitive market environment, they must adhere to the low-carbon management. Under the environment of low carbon economy, if private enterprises cannot clearly define the symbiotic and co-prosperous relationship between themselves and the environment and continue to adhere to the previous business philosophy, it will inevitably lead to the loss of competitiveness of private enterprises in the environment of low carbon economy. Therefore, in the process of development, private enterprises should not only focus on their own economic benefits, but actively change their previous strategic concepts to ensure that they can obtain the resources needed for their operation and development to the maximum extent without damaging the environment ${ }^{[1]}$. In addition, in the low carbon economic environment, private enterprises should not only focus on technological content and material changes as before, but also should take environmental improvement and the harmonious coexistence between people and the environment as the survival and development concept of private enterprises.

\subsection{Basic principles for implementing the low-carbon strategic concept}

In the process of operation and development, private enterprises should incorporate low-carbon development goals into their strategic development goals. The following basic principles should be followed in the concrete implementation of the low-carbon strategic concept.

First, strengthen the basic principles for the use of renewable energy. In the process of operation and development, private enterprises should gradually change from the previous energy structure with carbon as the main body to the non-carbon energy structure and the renewable energy structure. Ensure that the damage from renewable energy is less than the regenerative amount ${ }^{[2]}$. Wind power, hydro power, geothermal power, solar power, geothermal energy, and so on are all renewable energy sources, and one of the remarkable characteristics of these energy sources is that they are renewable. Private companies using these renewable resources need to recognize that renewable resources do not represent an inexhaustible supply. The amount of renewable resources is also limited. In the specific use of these energy resources, private enterprises must ensure that the amount used is less than the renewable amount, so as to ensure the self-resilience of the natural environment and energy.

Second, the basic principle of not using non-renewable energy sources should be adhered to as far as possible. At present, human beings still have not completely found a large number of products and technical means that can replace some non-renewable energy. Wanton use and waste for a long time, is bound to lead to the exhaustion of non-renewable energy. This will bring great challenges to the survival and development of future generations. Therefore, in the low-carbon economic environment, private enterprises must abide by the basic principle of not using non-renewable energy as much as possible in the process of development, so as to maximize the utilization rate of energy.

Third, strengthen the basic principles of carbon-based 
compound emission control. In the process of development, private enterprises should strengthen the use of renewable energy and reduce the use of non-renewable energy. At the same time, we also need to pay attention to strengthening the control of carbon-based compound emission. Private enterprises must ensure that their emissions of carbon-based compounds do not exceed the treatment technology and capacity,and let alone the purification capacity of the ecological environment itself.

\subsection{Make strategic decisions in a reasonable way}

Under the environment of low-carbon economy, in the process of development, private enterprises must reasonably make strategic decisions in accordance with the national requirements of energy conservation and emission reduction. Environmental variables are introduced into the decision-making system, and the environmental variables are regarded as independent factors, which have the right to veto the decision with one vote. In the past, in the process of economic development, a large amount of carbon emissions has become an irreversible fact ${ }^{[3]}$. Under the environment of low carbon economy, the development of private enterprises is more sensitive and fragile than any time in the past. Nowadays, the global climate is gradually warming, and natural disasters frequently appear. It seriously endangers the ecological balance, the development of agriculture and the security of water resources. Therefore, private enterprises can not ignore the environment when making any decisions. Under the environment of low carbon economy, the financial cost of private enterprises may increase in the short term. Private enterprises must adhere to the path of low-carbon operation to maintain a good reputation and performance. In the short term, it is difficult to show significant performance, but the life cycle of the enterprise will increase significantly, and the enterprise will obtain greater long-term development power. Private enterprises should gradually find out a strategic decision-making mode in line with the long-term development of enterprises under the environment of low carbon economy.

\subsection{Strengthening the implementation of the low-emission strategy}

In the past, in the process of operation and development, private enterprises did not put the governance of carbon-based compound emissions in a unified decision-making framework. Even some private enterprises have not considered the governance of carbon-based compounds at all, and have not included them into the scope of corporate responsibility. Under the environment of low carbon economy, this is bound to lead to the operation and development crisis of private enterprises ${ }^{[4]}$. Therefore, in the process of production and operation, private enterprises must pay attention to production and strengthen the implementation of low emission strategy. In order to protect our country's environment from the perspective of prevention. Specifically, private enterprises in the process of production, should reduce the amount of energy and materials used. For some materials that will cause damage to the environment, we must resolutely eliminate them in the process of production. As far as possible, use raw materials with higher energy and less pollution for production. Solve the problem of private enterprise carbon-based compound emission from the source. In addition, private industrial enterprises should also build carbon absorption and storage systems, using the system to absorb, transport and store carbon dioxide emissions. In the process of strengthening the implementation of low emission strategy, enterprises should also actively introduce the use of carbon capture technology and carbon storage technology. Actively participate in social activities such as desert management and afforestation to enhance the natural environment's ability to absorb carbon dioxide.

\section{Conclusion:}

To sum up, under the environment of low-carbon economy, private enterprises need to change their previous business philosophy and operation mode if they want to develop in a longer term. Private enterprises should not attach too much importance to their own economic benefits as in the past, but should strengthen the implementation of the energy-saving and emission reduction business philosophy and adhere to the path of low-carbon business. Under the environment of low carbon economy, private enterprises must face up to the opportunities and challenges they face. ${ }^{[5]}$ The enterprises take low carbon as the core of its strategic concept and implements the basic principles of low carbon strategic concept. The enterprises should reduce or not use non-renewable energy as much as possible, strengthen the use of renewable energy, ensure the renewable energy capacity, and promote its own development. Subject:

1.Project of the 13th five-year Plan for the development of philosophy and social sciences in Guangzhou in 2020, Project No.:2020GZGJ219

2.Guangdong Province General Colleges and universities young innovative talent category project in 2019, Project No.: 2019GWQNCX017.

\section{References}

1. Han Yaoxi. Analysis on the Difficulties and Development Strategies of Environmental Accounting -- Based on the Background of Enterprise Low-carbon Economy [J]. China Township Enterprise Accounting,2021(04):138-139.

2. Gao Yansheng, Zeng Xiaodong, Zhou Ben. Analysis of engineering economic risk and prevention management strategy under the background of low-carbon economy [J]. Marketing Industry, 2021(07): 47-48.

3. Jing Wen. Research on the Green Development of 
Garment Foreign Trade Enterprises from the Perspective of Low Carbon Economy [J]. Cotton Textile Technology, 201,49(02):100-101.

4. Wang Ling. Opportunities and Challenges of Green Accounting Development under the Low-carbon Economy $[\mathrm{J}]$. Contemporary Agricultural Machinery,2020(08):79-80.

5. Jia Xueying. Research on Evaluation of Low-carbon Economic Development Level of China's Coal Enterprises Based on Rough Set [D]. Xi 'an University of Science and Technology,2020 